\title{
BALI: Towards a Green Island
}

\author{
Deddy Kurniawan, HALIM, Green Building Council Indonesia, Bali, Indonesia \\ Ida Bagus, SETIAWAN, Office of Energy \& Mineral Resources, Bali, Indonesia
}

\begin{abstract}
On the 28 October 2019, the Government of Bali issued a Governor Ordinance No. 45/2019 prioritising(?)clean energy as the solution to the energy crisis in Bali. This crisis has been further exaserbated by the covid 19 pandemic which has decimated the Islands economy in particular, tourism, its primary industry. This has forced Bali to change its tourism orientation from urban tourism to rural tourismpromoting homestay, a shift which will signifcantly influence renewable energy planning for the Island. There are only two solar power plants on the island; one in Bangli and one in Karangasem each with $1 \mathrm{MWp}$ on-Grid capacity. In addition there is a small hydro power plant in Buleleng with 1,95 MWp capacity, with existing rooftop PV power plant in the community generates around $1.3 \mathrm{MWp}$ and $0.07 \mathrm{MWp}$ off-grid. This leaves the Island with a signficant shortfall and must, in acocrdance with the Ordinance, be met through the promotion of community uptake of solar panel for homes and buildings. This paper presents the of the strategic planning approach used by a special task force supervisory team of Bali Clean Energy to implement the Ordinance for the island
\end{abstract}

Keywords

Renewable Clean Energy, Governor Ordinance, Energy for Tourism

\section{Background}

Electricity on Bali was primarily supplied by oil and coal fired power plants from Java. These relied on national oil reserves which ran out in 2019 requiring Indonesia to become a net oil importer, while coal reserves will runout by 2025 . This critical condition, anticipated by the Central Government, resulted in the issuing of Ordinance No. 79/2014, a revision of the previous Presidential Ordinance No. 5/2006 on National Energy Policy. Bali has nine local governments with eight regencies (Badung, Tabanan, Bangli, Karangasem, Klungkung, Jembrana, Buleleng, Gianyar) and one municipality (Denpasar), which is also the capital city. Transition to the use of clean energy is complicated by the ongoing construction of coal-fired power plant in Celukan Bawang, which is projected to produce $780 \mathrm{MW}$. It's continuing development is still in public debate because it is based on coal and the capacity, planned by state owned electricity company (PLN-Bali), cannot meet the immediate need of $1200 \mathrm{MW}$ and expected increases beyond.

Implementation of the Bali Government's vision of "Nangun Sat Kerthi Loka Bali", will have a significant impact on renewable energy planning. The vision for the Island which will be implemented through the Development Scheme of Total Planning towards a New Era of Bali, will be carried out across 22 missions. These missions prioritize 5 (five) sectors; 1) Clothing, Food and Housing; 2) Health and Education; 3) Social Security and Employment, 4) Customs, Religion, Tradition, Arts and Culture, and 5) Tourism. These five priority sectors will be supported by integrated infrastructure investment and development on land, sea, and air with an emphasis on the utilization of clean energy. The vision will be delivered through a comprehensive and integrated planning approach within the framework of Unitary State of the Republic of Indonesia. It is committed to maintaining the purity of Bali's natural environment, by pursuing a prosperous Balinese life, both physically and metaphysically, in accordance to three principles: Political Sovereignty, Economic Independence, and Cultural Personality. 


\section{Regulation}

\subsection{National Regulation}

Energy is expected to make a positive impact in Indonesia and therefore has a significant role to play in economic growth and national resilience. It is also important therefore that energy management which involves supplying, utilization, and energy mining is executed wisely, in terms of fairness, optimality, rationality, and sustainability.

In Indonesia the regulation of energy management practices is goverened by the following four regulations:

a. Republic of Indonesia Law No. 30/2007 concerning Energy.

b. Republic of Indonesia Law No. 30/2009 concerning Electricity.

c. Government Ordinance No. 70/2009 concerning Energy Conservation.

d. Government Ordinance No. 79/2014 concerning National Energy Policy.

Because the Republic of Indonesia is an archipelago nation divided by three time zones (west, central, east) with 34 provinces, it uses a unitary rather than federal system through which to guide the preparation and implementation of these regulations through energy management plans. , Bali is a Province located in the central time zone (refer Fig.1) .

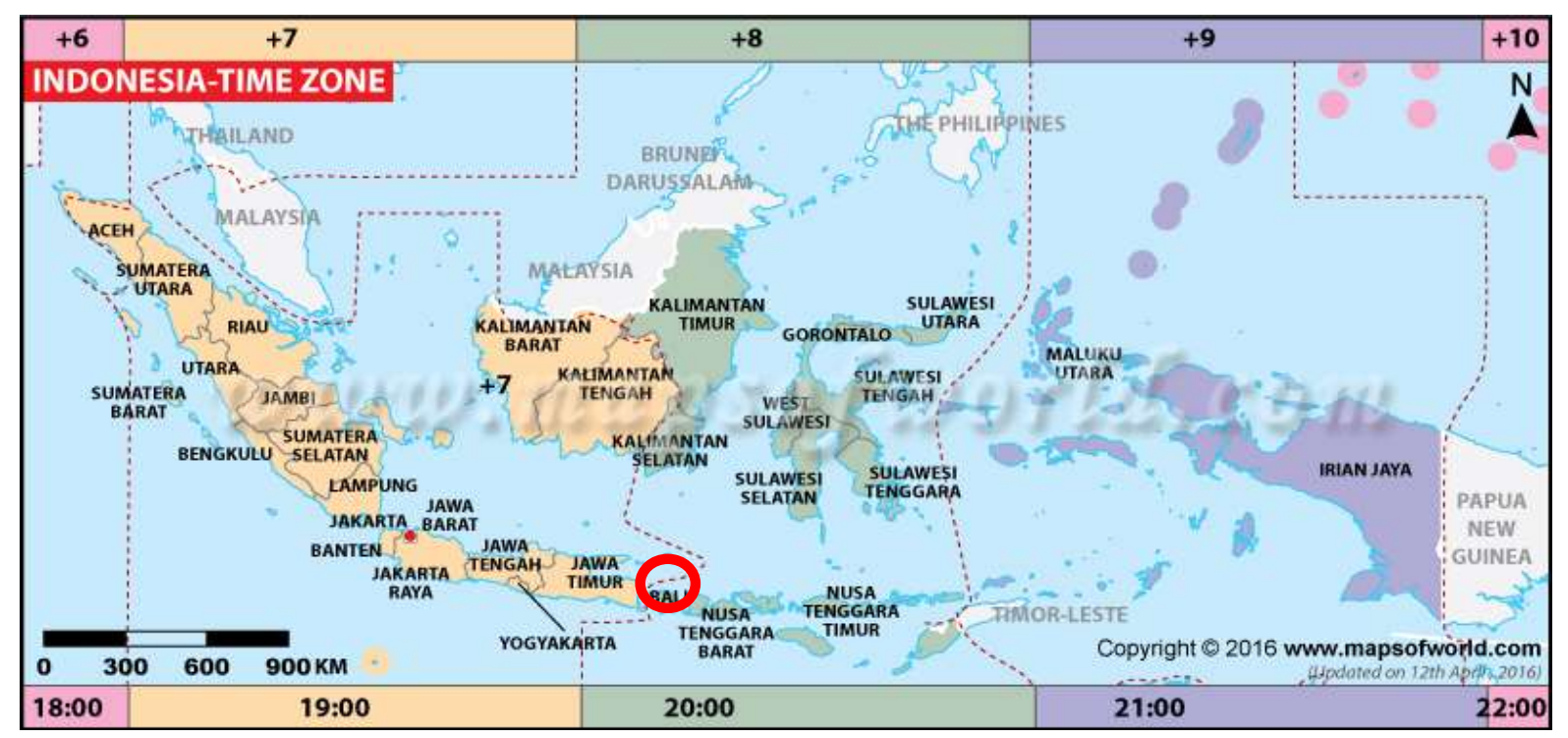

Figure 1. Bali in Indonesia archipelago with three time zone. Source: mapsofworld.com

\subsection{Provincial Regulation}

As noted previously, the regional development vision of "Nangun Sat Kerthi Loka Bali" which is to create an island which is clean, green, beautiful, thus maintain purity and harmony, requires pro-environment attitude and energy conservation approach.. To achieve this goal, energy management should be based on the Balinese values of "Tri hita Kirana", the balance between environment, cultural-spiritual, and social-economic, or Triple Bottom Line of social, environmental and economic.

To enable this approach, provincial regulations must be adapted to reflect the cultural values and Balinese way of thinking. There are six umbrella regulations that guide energy development and management in the province:

a. Provincial Law No. 2/2019 concerning Long-Term Development Plan of the Bali Province 2005-2025.

b. Provincial Law No. 3/2019 concerning Medium-Term Development Plan of Bali Province 2018-2023. 
c. Provincial Law No. 3/2020 concerning Amendment to Regional Regulation No. 16/2009 concerning Bali Provincial Spatial Planning for 2009-2029.

d. Governor Ordinance No. 45/2019 concerning Bali Clean Energy.

e. Governor Ordinance No. 48/2019 concerning Battery-Based Electric Motor Vehicles.

f. Decree of Bali Governor No. 123/03-M/HK/2020 concerning the General Plan for Regional Electricity of Bali Province 2020-2039.

The Draft Bali Provincial Energy General Plan (Rencana Umum Energi Daerah-Provinsi / RUED-P) 20202050 was developed in consultation with the Indonesian Ministry of Home Affairs and approved and immediately enacted by the Bali Provincial House of Representatives (DPRD Bali) in July 2020.

\section{Recent Major Research on Renewable Energy in Bali}

Several recent studies show that there is significant potential to generate renewable energy in Bali. In 2019 a joint study by CORE (Centre of Community Based Renewable Energy) Udayana University and Greenpeace, produced a Road Map of Solar Roof Power generation across the island. It highlighted the huge potential for roof-based solar energy generation throughout the island suggesting up to $108 \mathrm{MWp}$ could be generated by 2025. (CORE, 2019)

In another study by the Bali branch of the state owned electricity company, a survey of household customers of $>10$ kVA who use Solar Roof Power Plant for maximum of $20 \%$ from the installed potency, as a mandated by the Governor Ordinance No. 45/2019 is around 159 MWp. (PLN UID Bali, 2020)

In 2019, a joint pre-feasibility study conducted by Directorate General of Renewable Energies and Energy Conservations, Ministry of Energy and Mineral Resources of the Republic of Indonesia and the IESR (Institute for Essential Services Reform), also found that there was potential to generate approximately $340 \mathrm{MWp}$ from all kind of Renewable energy sources across Bali.

Giriantari (2020) also cited the RUEN (National Energy General Plan) 2018-2050 assertion that the potential for renewable energy generation in Bali could reach up to 3,061.6 MWp if a combination of the following sources were employed; Geothermal $262 \mathrm{MWp}$, Hydro $208 \mathrm{MWp}$ (plus $15 \mathrm{MWp}$ from Mini/Micro Hydro), Bioenergy 191.6 MWp, Solar 1,254 MWp, Wind 1,019 MWp, and OTEC (Ocean Thermal Energy Conversion) $320 \mathrm{MWp}$ with only 4.2 MWp have been already realized of Mini/Micro Hydro $2 \mathrm{MWp}$, and Solar 2.2 MWp.

\section{Renewable Energy}

\subsection{Potentials of Renewable Energy}

The are several potential sources of renewable energy in Bali, these are sun, water flow and waterfall, wind, geothermal, bio energy, movement, temperature differences in ocean layers and hydrogen. Based on the results of technical studies, the greatest potential for energy generation comes from the sun with the potential to produce 1,500-1,600 kWp of power.

According to government assessments(?), the greatest potential to accommodate renewable energy infrastructure is in coastal areas and open spaces. Within these, the priority is to utilize government buildings, both provincial and municipal level, commercial buildings, industrial plants, tourism developments, and public facilities as shown in the table 1, for the purposes of installing rooftop solar infrastructure. 
With regards to Hydropower, the potential exists to enable microhydro (500-100 kW), mini hydro (100 kW-1 MW), and potential to enable picohydro (max. $500 \mathrm{kw}$ ) generators, particularly in mountain areas such as Jatiluwih in Tabanan region which is dominated by rice production, and serves as a regional hub for rice storage. Feasibility studies have also suggested that the tourism

\begin{tabular}{|c|c|c|c|}
\hline No. & Type & $\begin{array}{l}\text { Potency } \\
\text { (MW) }\end{array}$ & Obstacle \\
\hline \multirow{2}{*}{1} & Hydro & 208.00 & \\
\hline & a. Microhydro \& Minihydro & 15.00 & Ineffective usage \\
\hline 2 & Solar & $1,254.00$ & Land \& Economic Scale \\
\hline 3 & Wind & $1,019.00$ & Technology \& Economic Scale \\
\hline 4 & Geothermal & 262.00 & Sociocultural values \\
\hline 5 & OTEC (Ocean Thermal Energy Conversion) & 320.00 & Immature Technology \\
\hline \multirow{3}{*}{6} & Bio energy: & & \\
\hline & a. Biomass (incl. Waste to Energy) & 146.90 & Tipping Fee \\
\hline & b. Biogas & 44.70 & \\
\hline \multicolumn{2}{|r|}{ Total } & $3,269.60$ & \\
\hline
\end{tabular}
developments in the area are suitable for picohydro generation.

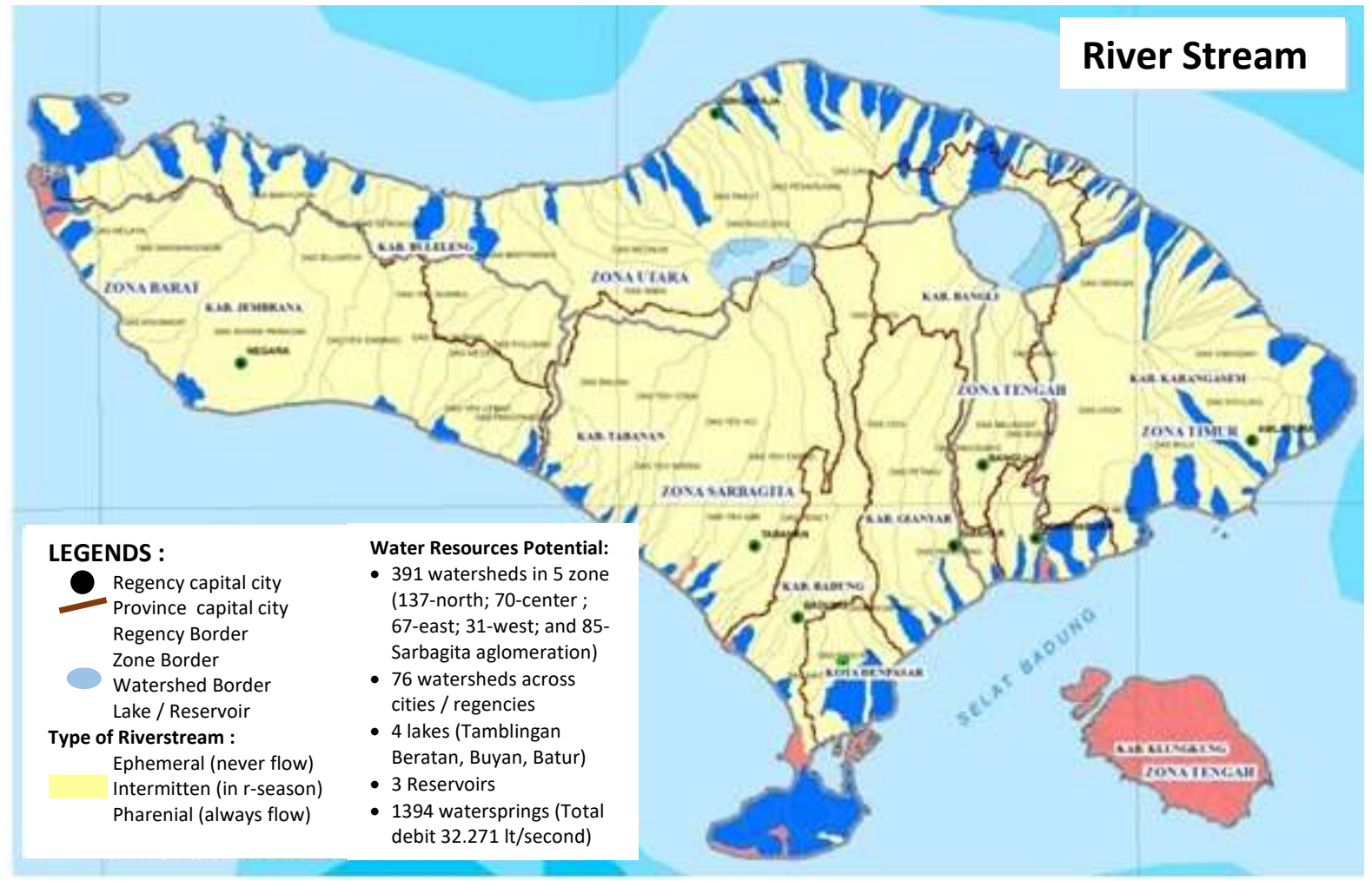

Figure 2. Water stream \& Water resources potential. Source: Spatial Planning of Bali 2009-2029

Apart from its potential to generate renewable energy, Jatiluwih's Subak traditional irrigation system has also been recognised as a UNESCO World Heritage Site. The picohydro using Subak is also potential to be promoted in tourism developments and the output could be used at least for street lighting. (see figure 3)

While the CORE (2019) study notes that Rooftop solar has the potential to produce around 1,490 - 1,776 $\mathrm{kWh} / \mathrm{kWp}$ per sq/m annually, it is vulnerable to the vagaries climactic conditions characteristic of tropical regions. During rainy and cloudy weather, the potency of renewable energy sources such as the sun are reduced significantly, requiring therefore the utilization of hybrid technologies, using electricity smart systems., reducing high cost investment as well as maintenance, and choosing good quality product. 


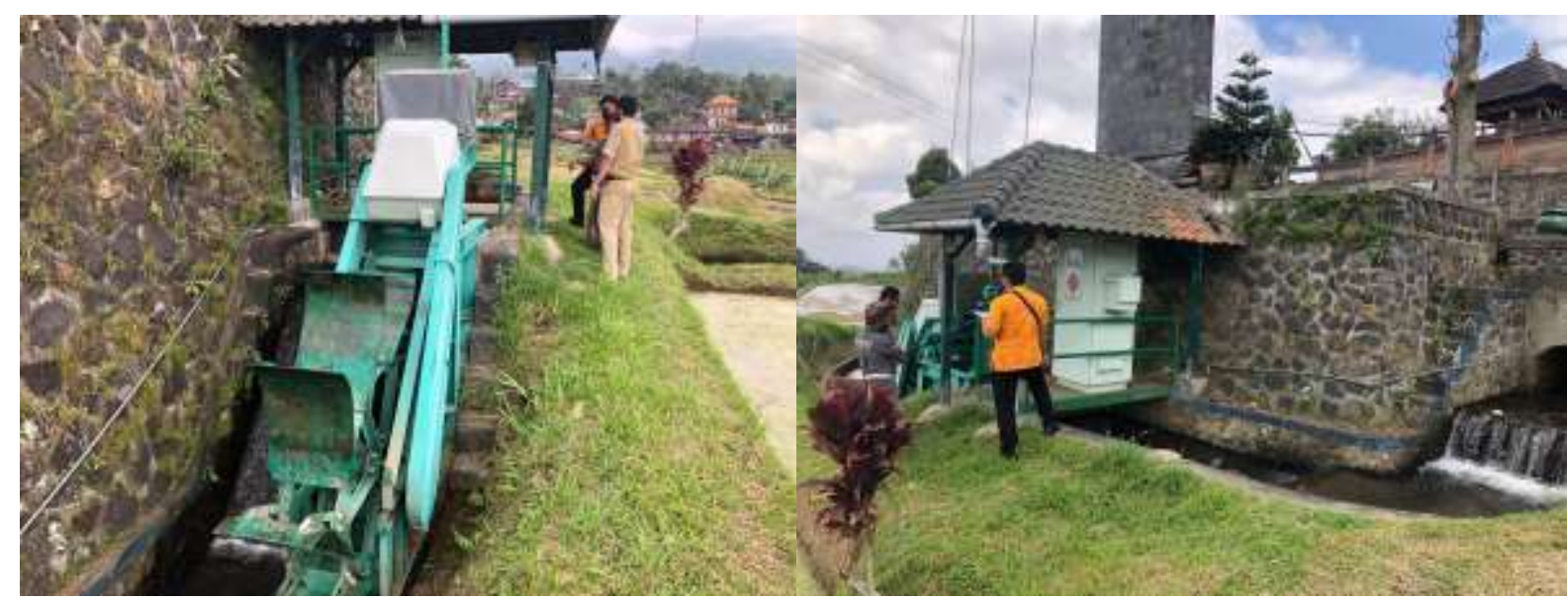

Figure 3. Piko hydro using Drainage \& Irrigation system (Subak) in Jatiluwih. Source: field survey 2020.

According to the Global Solar Atlas, Bali is well positioned to generate $1,286 \mathrm{kWh} / \mathrm{kWp}$ on average with its peripheral areas in the south, north west and north east providing the best locational value. While the PLN-Bali's 2020 target for photovoltaic output is 159MW, CORE study suggests this may be compromised due to climactic variability and will increase up to $182 \mathrm{MW}$ in 2022 optimistically for Hotel/Tourism, Government/Publics, Business/Commercials, Housing, and others. But CORE predicts the number achieved is only $108 \mathrm{MW}$ due to the intermittent nature of solar power. (Giriantari, 2020).

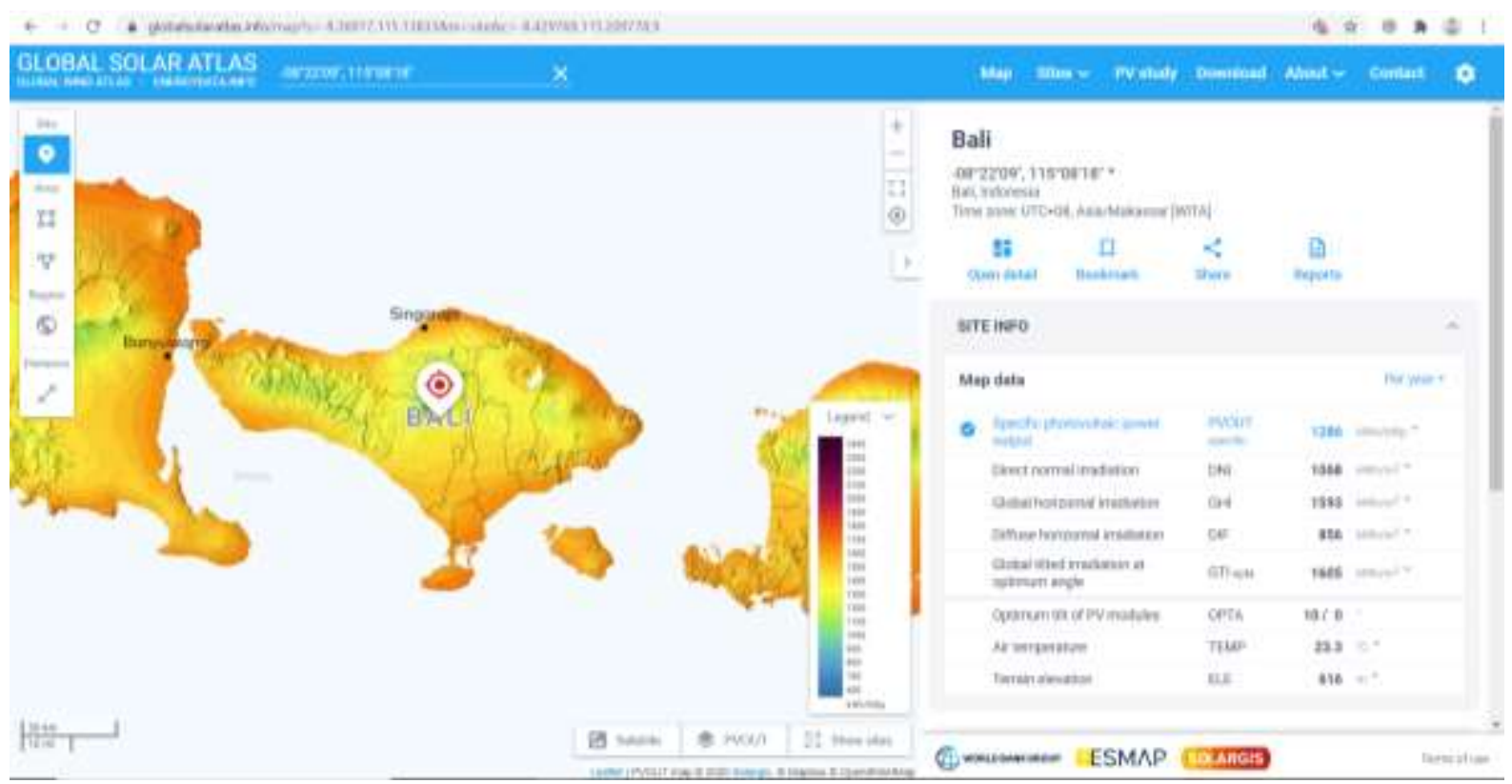

Figure 4. Bali's Photovoltaic Power Output Potential. Source: Global Solar Atlas

\subsection{Existing of Renewable Energy}

According to a field study conducted by PLN-Bali, Amoghasiddi Community Cooperative, notes that as of August 2020, there are approximately 130 Rooftop solar Power Plants installed across Bali with an output of $\pm 1.500 \mathrm{kWp}$ or equivalent to $1,5 \mathrm{MWp}$ and with a potential to generate of $\pm 300-400 \mathrm{MWp}$ for the total potency of installation. 


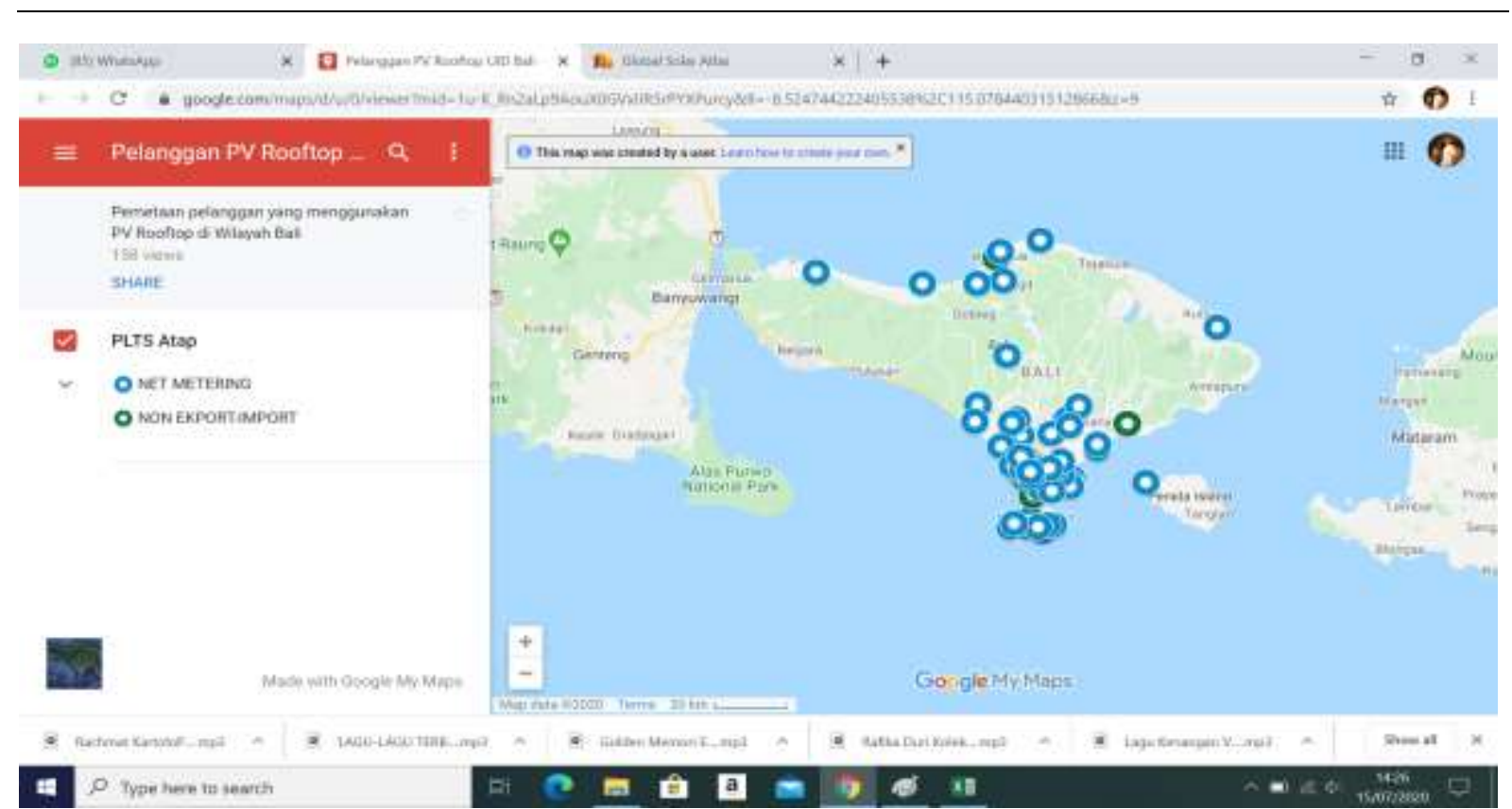

Figure 5. Existing Solar Roof Power Plants. Source: PLN Bali, Cooperative Amoghasiddi, Field Survey

Several pilot rooftop solar power plant projects have been installed in Bali by the central government, provincial governments, municipal governments, PLN, Independent Power Producer (IPP), universities, tourism industry, and the public. The Central Governments Renewable Energy and Resilience Research and Development Agency (P3TKEBTKE) of the Ministry of Energy and Mineral Resources, has collaborated with the Bali Government to develop these pilot projects as part of the Bali Governor's Office microgrid system. As part of this cooperation scheme the Bali Government prepares rooftops for installation and the Ministry of Energy and Mineral Resources installs the solar PV infrastructure, each with a capacity to generate $158 \mathrm{kWp}$ which has been deducted from PLN's grid supply (Giriantari, 2019). In remote areas where there is no aces to grid power, small scale solar power plants have also been installed.

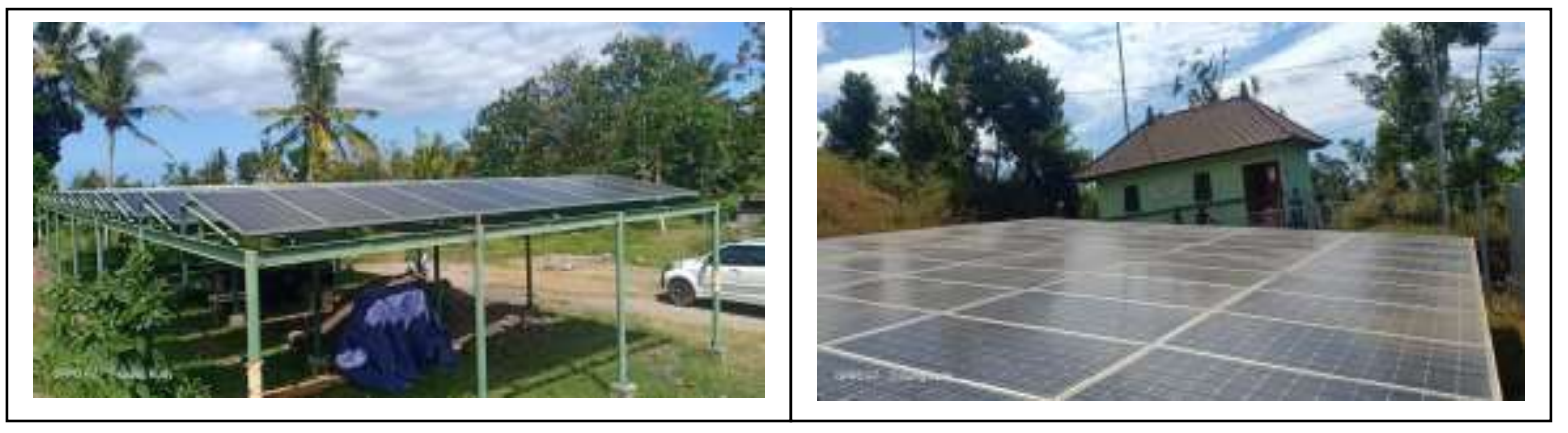

Figure 6. Solar Power Plant $23 \mathrm{kWp}$ in Klungkung for irrigation and $10 \mathrm{kWp}$ in Karangasem for electricity for 18 households \& 3 public facilities. Source: Field Survey 2020.

\subsection{Planning \& Development of Renewable Energy}

As noted previously, Bali's electricity, typically supplied by PLN from power plants in Java Island, were fossil fuelled based. With petroleum supplies running out and coal supplies expected to run out by 2025, PLN-Bali has been preparing feasibility studies and transition plans to anticipate the energy crisis. To inform this PLN-Bali has been modelling Bali's potential $10 \mathrm{yr}$ Energy Mix/ projections as shown in Figure 7. These projections are important in helping transitioning Bali's shift to renewable energy sources before fossil fuels run out entirely. 


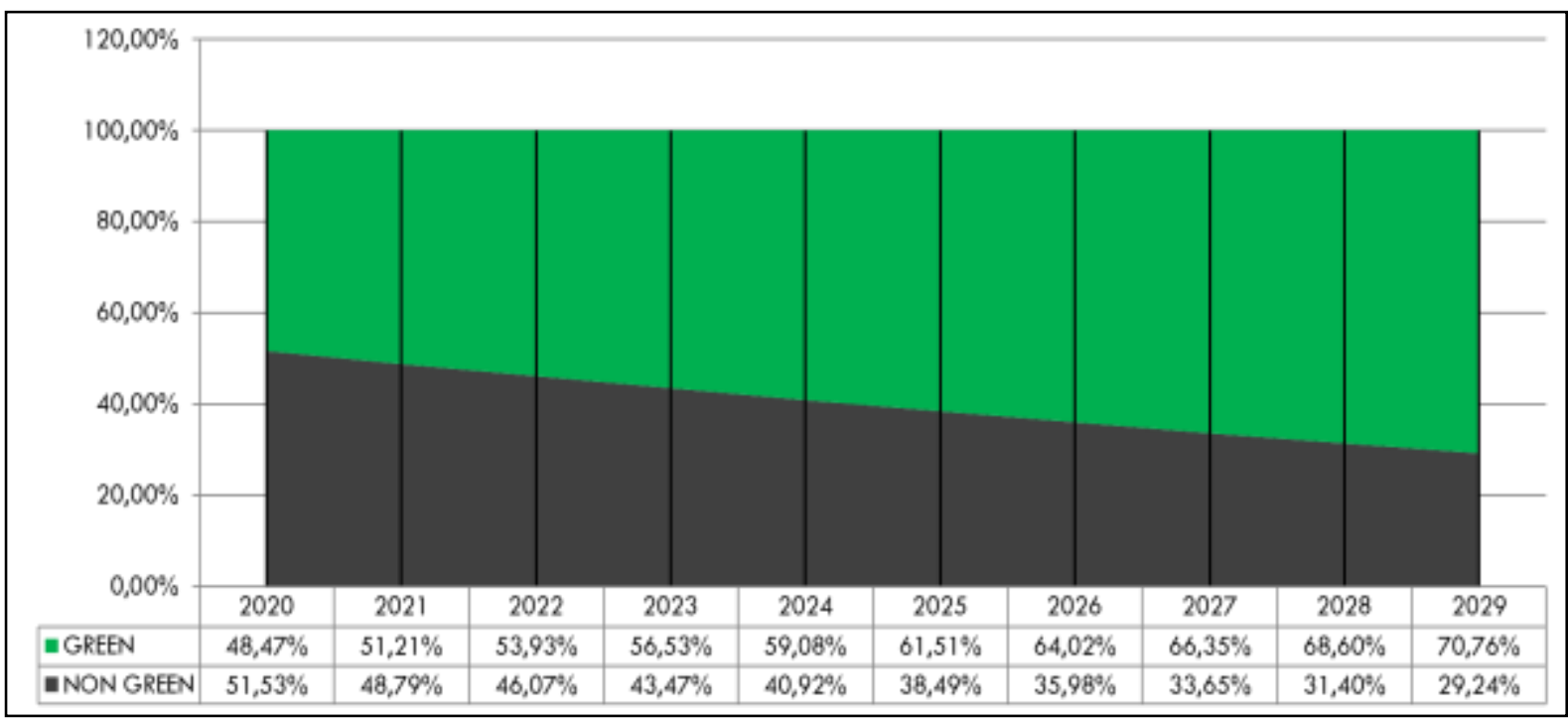

Figure 7. Energy Mix Projection 2020-2029. Source: PLN--Bali), 2020.

Therefore, to realize these projections, PLN--Bali has already planned and developed the development of several renewable energy power plants across the island. Figure 8 and 9 below show some of the primary locations for the development of renewable energy infrastructure in accordance to with the Renewable Energy master plan.

Meanwhile, the Provincial Government of Bali enacted regional regulation No. 3/2020 recently to enable the development of a clean energy industrial estate located in the west of the Island in the Candi Kesuma area of Jembrana Regency. This new Regulation amended Bali Province's 2009-2029 Spatial Planning Provincial Regulation No. 16/2009 so that hundreds of hectares could be developed, as shown in the Figure 10, that regulates to support Clean Energy industry and drive the utilization of Clean Energy in Bali.

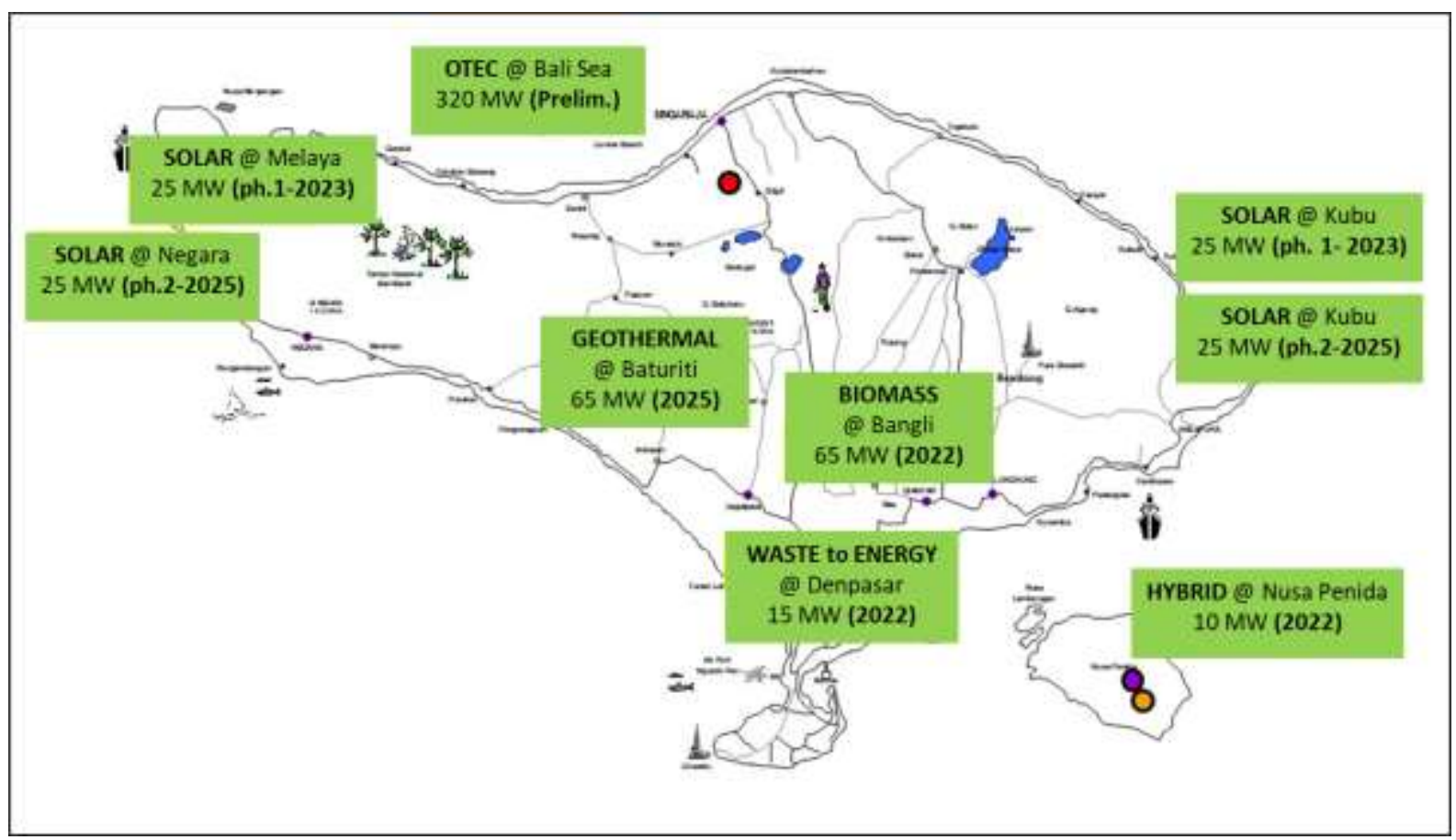

Figure 8. Planning of Renewable Energy. Source: PLN--Bali), 2020. 


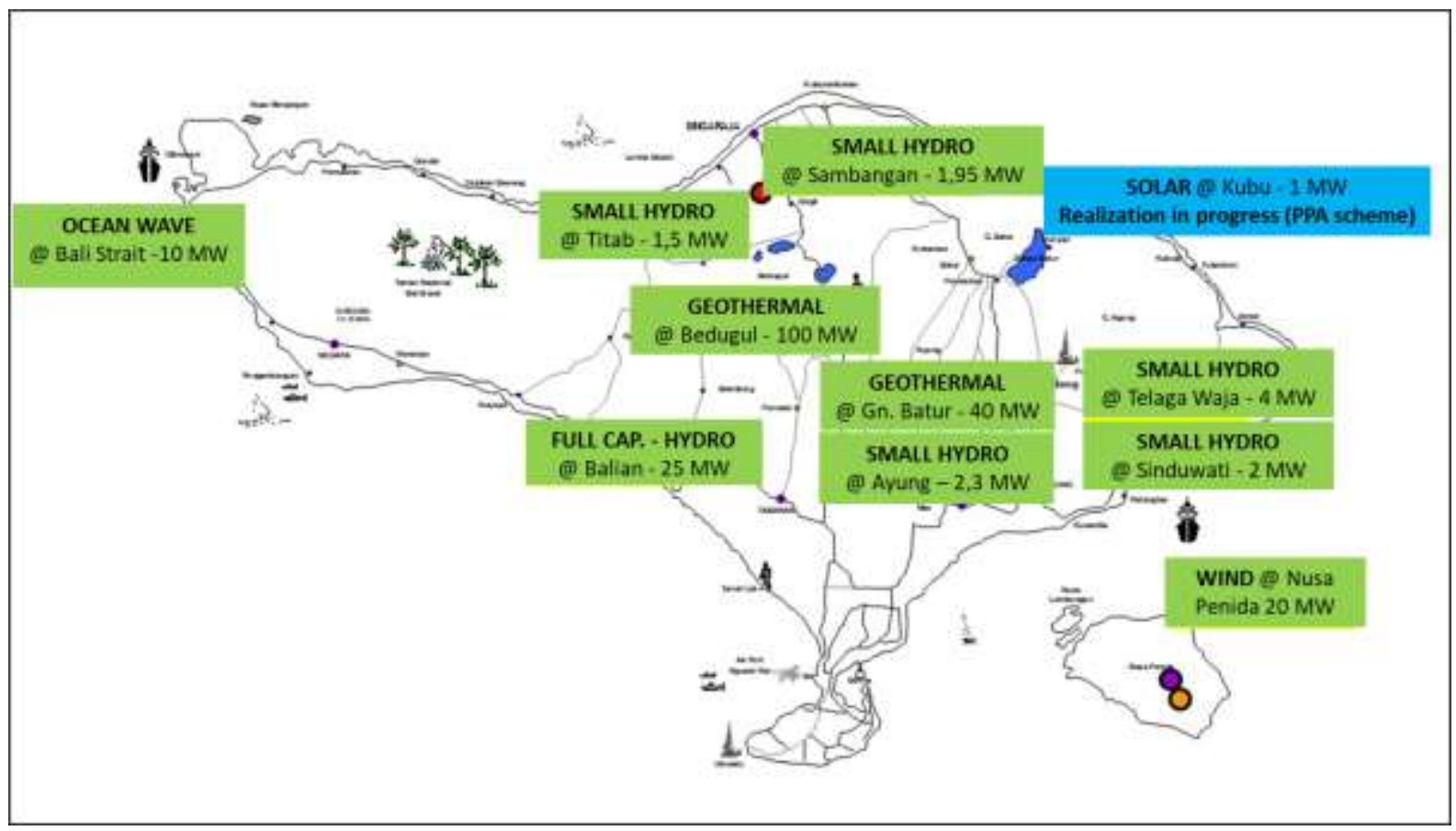

Figure 9. Development of Renewable Energy. Source: PLN -Bali, 2020.
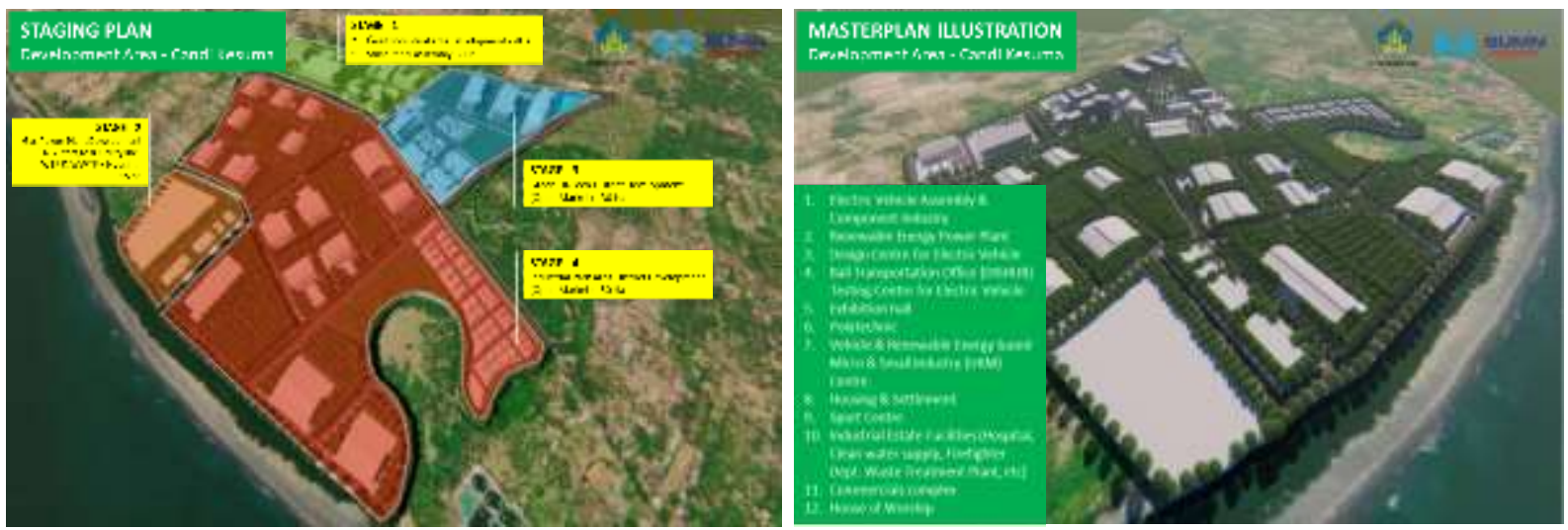

Figure 10. Clean Energy Industrial Estate. Source: Perusda Bali, 2020

\section{Challenge for Waste to Energy}

There are growing discussions about processing waste to be Refuse Derived Fuel (RDF) in Bali. One of the biggest crisis confronting the Island is that of waste generation and disposal.. This is a critical condition made worse by the influx of millions of tourists to the Island each year. In 2019 alone, 6,5 million tourists visited Bali, twice as many as the existing Balinese population. To manage the issue of waste, the Central Government initiatied a national Waste to Energy (WtE) program. This program aims to look at RDF as part of a hybrid solution to coal-fired electricity. Processes such as gasification have been found to offer promising WtE outcomes and benefits. Advanced Gasification has several advantages over other waste management methods. It is; 1) carbon negative, 2) reduces waste stench/ odours, 3) has no smoke pollutant, 4) creates no new waste (i.e. polluting ash produced by the Incinerator), 5) RDF is a byproduct 6) has no hazardous emission such as Dioxins and Furan, and 7) creates no toxin or leachate to pollute air or soil. It will contributes to reducing greenhouse gas emissions and in turn global warming. To aid transition to WtE technologies, the Central Government is encouraging each province to promote WtE 
with the Bali Government taking it one step further by opening up business related opportunities and giving every municipal government the authority to regulate its own schemes. These include developing Business to Businnes (B to B) and Public-Private Partnership (PPP) schemes.

However, implementing WtE needs careful planning and secured schemes, so that PPP between government and business entity will be accompanied by PT. Penjamin Infrastruktur Indonesia, a state owned company who is responsible as a project guarantor, under the Directorate General of Public Works Infrastructure and Housing Financing - Ministry of Public Works and Housing.

In Bali, planning is already underway for a provincial WtE plant plan, located in Suwung Denpasar and serving Sarbagita metropolitan area, an area which includes the capital city (Denpasar) and three regencies (Badung, Gianyar and Tabanan). The aim is to utilise current waste dump sites, with potential energy generated exceeding $15 \mathrm{MW}$. This is now going through Full Business Case (FBC) development with a review a Feasibility Study being undertaken in to the establishment of a PPP. This will be followed by full design development of the proposed facilitybefore undertaking Market Sounding stage, and eventually going to public Tender.

\section{Green Energy and Tourism Development in Bali}

As noted earlier, the island's primary economic source, tourism, has suffered signifcantly during the Covid-19 pandemic causing hundreds of hotels to close and most supporting industries to be shutdown., This has forced the Government to change its tourism orientation from urban tourism to rural tourism with an emphasis on homestay eco tourism. This has given rise to developments such as the locomotivee' an Eco Tourism Village (ETV). as. The ETV has been designed to enable social distancing with 4 kinds of recreation offered; Ecotourism, Agrotrourism, Adventure Tourism, and Cultural Tourism (Halim, 2020). The ETV also promotes community based homestays and villas rather than private hotels (corporate) and in so doing will strongly influence the investment in the uptake of domestic renewable energy infrastructure such as Solar PV.

According to Bali Provincial Energy General Plan (RUED-P) 2020-2050, the energy requirement in tourism sector is very high, around 50-60\% from total energy required in Bali.

While the Covid-19 pandemic has affected all parts of life, recovery and regeneration of the Islands economy also presents an opportuntiy to improve both the quality of Bali tourism experience by supporting it with clean green renewableenergy infrastructure and by establishing a brand new industry capable of attracting new investment, creating new jobs and supporting families and communities.,.

According to Bali's Central Statistics Agency (BPS-Bali), as of 2019 Bali had developed 110 ETV, , an increase ofby $124 \%$ in four years. . This has been complimented by an increase in the number of ordinary villages offering 'homestay' opportunities which have risen by $32 \%$ to 162 villages, an increase from 122 villages in 2014 (Purwanto, 2019)

Some ETV's generaterenewable energy and top up local electricity supplies for the village. Most of them also implement Waste to Energy (WtE) to meet energy demand. In Klungkung regency, a small scale WtE changes its waste into RDF (Refuse Derived Fuel) in the form of briqquetes, a block of compressed charcoal dust or organic waste which can be used as fuel.

The ETV of Sudaji in Buleleng regency takes this one step further by creating an integrated waste treatment plant/WTP (Tempat Pengolahan Sampah Terpadu / TPST) with a sorting and recycling facility funded by the Sudaji community initiative. Other remote villages on other island have built WtE gasification system (closed combustion) power plants using foreign grants because incinerator system (open combustion) are not encouraged by the applicable law in Indonesia due to environemal hazzards 
and air polution. Gasification can produce syngas (synthetic gas) that directly can fuel the power plant. On Siberut island, there are three bamboo based biomass power plants with total outpout of $700 \mathrm{~kW}$ (Matotonan Village - $150 \mathrm{~kW}$, Saliguma Village - $250 \mathrm{~kW}$, Madobag - $300 \mathrm{~kW}$ ) using gasifications technology (Wahono, 2020)

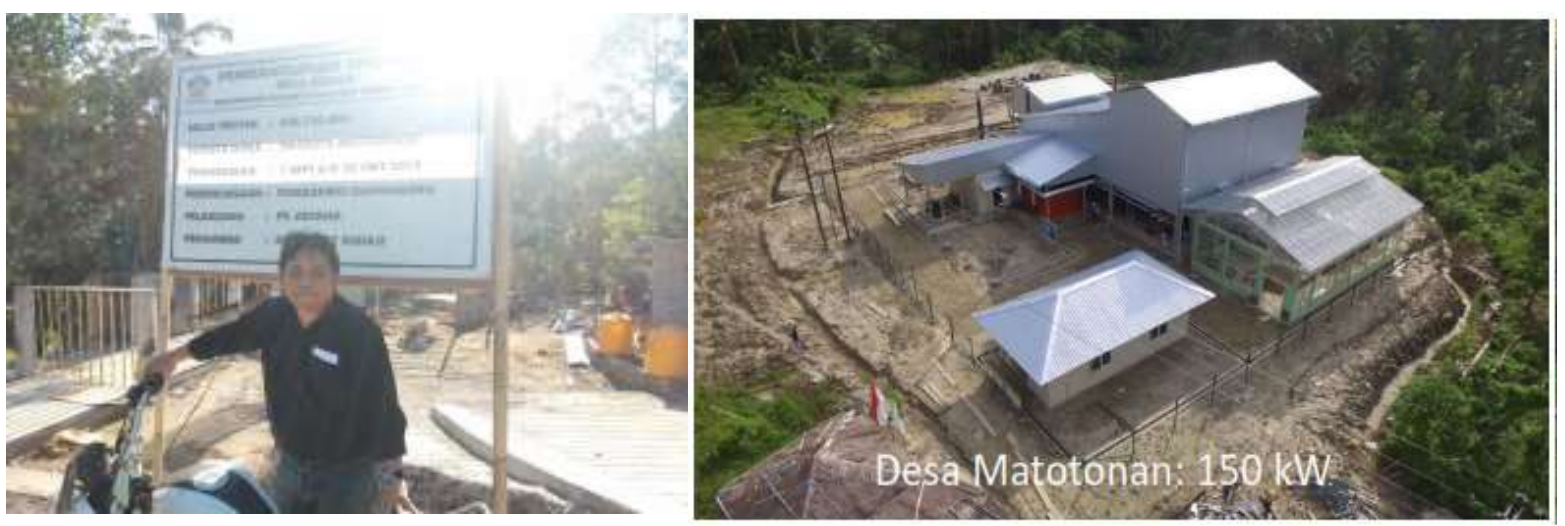

Figure 11. Integrated WTP in Sudaji Eco Tourism Village, Bali and Gasification in Matotonan Village, Siberut Island- Mentawai. Source: Field Survey, 2019 \& Wahono, 2020

The tourism industry is very closely related to the provision of buildings for accommodation and places to eat and entertainment centres. These buildings are very large in number because of the tourism is a major industry in Bali. In response to the economic crisis brought on by covid, the tourism sector has begun to promote solar power as part of a sustainable green tourism movement that can help to improve competitiveness and corporate image. An example of this is the Waterbom Park in Kuta. It has installed a $156 \mathrm{kWp}$ solar PV to reduce the supply from PLN-Bali. This is an example of cooperation business model referred to as a B to B scheme. Under this type of modela solar roof contractor builds the solar roof power plant on a building owned by Waterbom and sells its electricity to Waterbom Park. Several other hotels in Bali, such as Mercure at Bypass Ngurah Rai - Kuta, Long House Resort at Goa Gong, and Royal Tulip Hotel (also known as Springhill Condotel) at Jimbaran Hijau, are also progressively installing solar PV on roofs. These are arein the South Kuta district,Badung regencyshown in Figure 12.

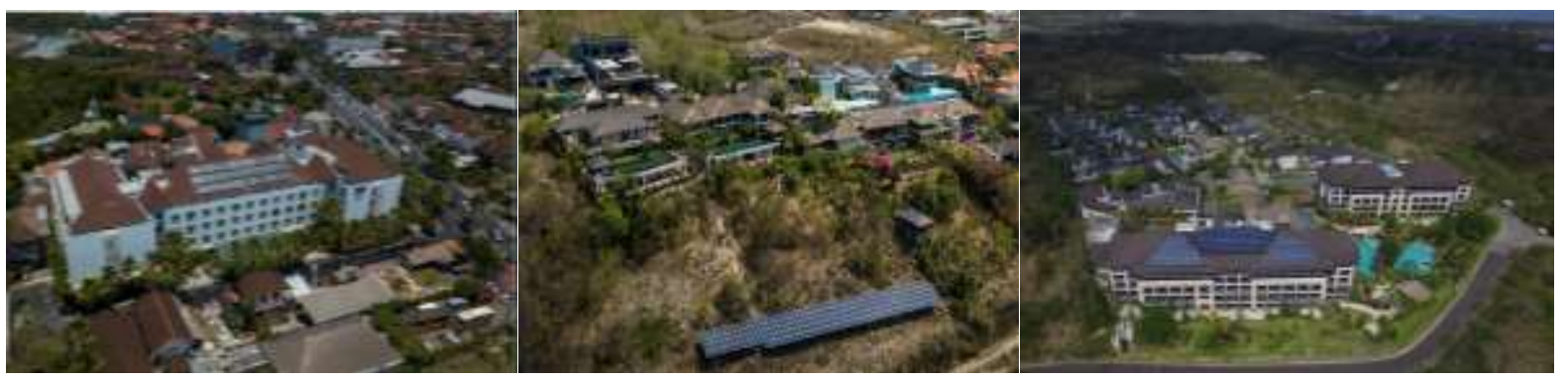

Figure 12. Hotels with Solar Roof Power Plant: Mercure at Kuta, Longhouse at Goa Gong, Royal Tulip (a.k.a. Springhill Condotel) at Jimbaran Hijau. Source: Peta Jalan - CORE, 2019 \& Jimbaran Hijau, 2020.

Some hotels such as Springhill, Condotel have been awarded EDGE certificate, a green buidling certification given by the International Finance Corporation (IFC-World Bank) for excellence in design. This hotel has also been recognised for usingless embodied energy in building material, and for water and energy savings thorugh the use ofSolar PV panel and an applied water conservation systems as seen in Figure 13.

Springhill uses several technciques to deliver thse savings. It has reduced window to wall ratio, external shading devices, insulation of roof and external walls, natural ventilation in corridors, air conditioning 
with air cooled screw chiller, energy-saving light bulbs for internal and external spaces, and solar photovoltaics. For water conservation, It uses low-flow plumbing fixtures for washbasins and showerheads, dual-flush water closets, water-efficient urinals, water-efficient kitchen faucets, and waterefficient landscaping. It terms of minimising embodied energy, it utilized micro concrete tiles on steel rafters for roof construction, stone profile cladding and autoclaved aerated concrete blocks for internal and external walls, wood block finishes for flooring, and timber window frames.

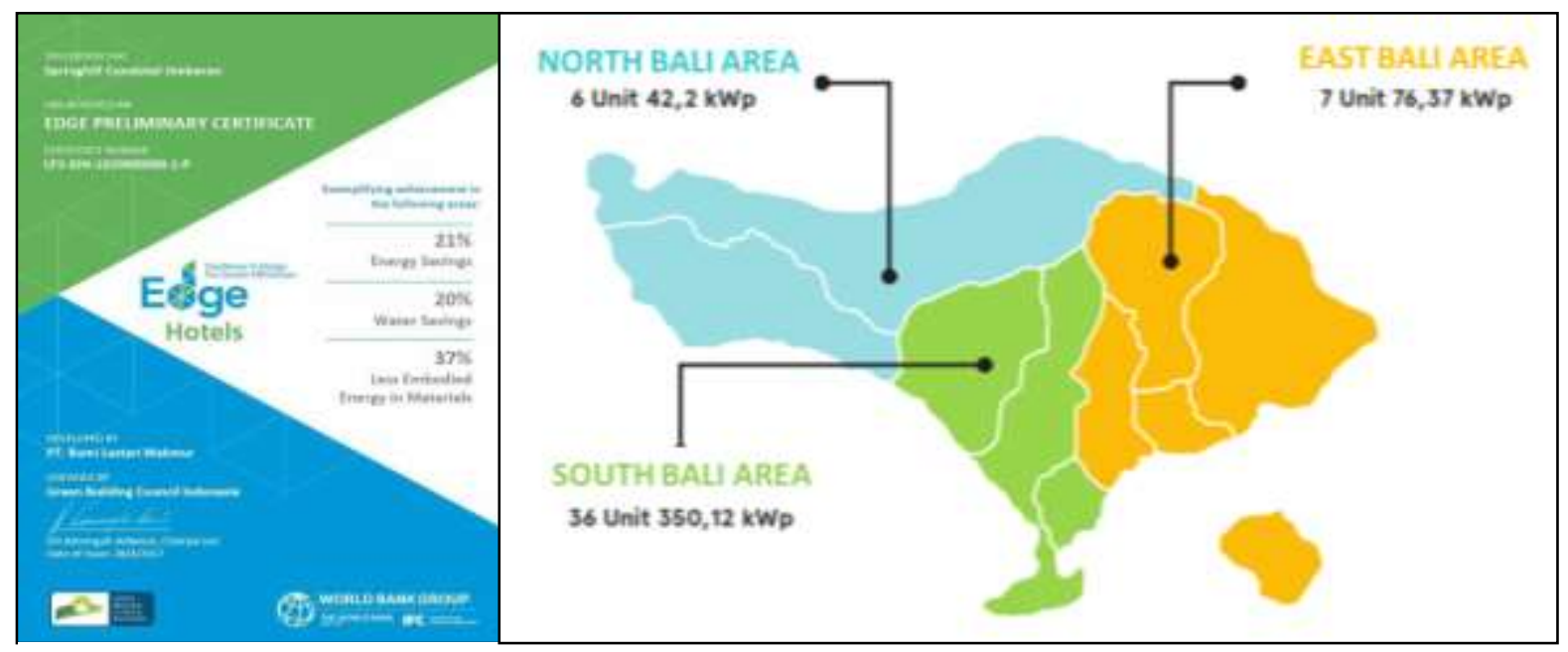

Figure 13. EDGE certification by IFC-World Bank and Distribution of Solar Roof Power plant in Bali. Source: Jimbaran Hijau, 2020 \& Peta Jalan - CORE, 2019.

According to PLN-Bali) data,installation of roof-top solar has increased across Bali. From mid-2019 there are now 49 units scattered in South Bali - 36 units, East Bali - 7 units, and North Bali - 6 units with a total installed capacity of around $470 \mathrm{kWp}$. (refer to figurebelow).

\section{Strategy and Implementation}

\subsection{Strategy}

The utilization, development, and management of renewable energy must be carried out hand in hand between competent parties. Strong commitment is required to achieve energy independence and security. Local Government, in this context, is not only critical to developing regulations but also as pioneers leading regional innovation in the development of renewable energy.

There are several delivery models which can be used to advance investment and cooperation between government and government ( $G$ to $G$ ); government with business entity ( $G$ to $B$ ) or sometimes also called PPP (Public-Private Partnership), and business entity with business entity (B to $B$ ).

For B to B scheme, usually investor (private or state/provincial owned enterprise) would joint venture with Perusda (Bali province owned enterprise) as the IPP (Independent Power Producer). Nevertheless, in erecting power plant, whatever scheme is chosen ( $G$ to G, PPP or B to B), every IPP has mandatory PPA (Power Purchased Agreement) with PLN as the buyer of the electricity produced, so that there is an assurance in doing energy business in Indonesia in general, and Bali in particular.

\subsection{Implementation}

The local government accelerates the process in realizing Resilience and Competitiveness, particularly in developing renewable energy. In addition to issuing a number of regional regulations (Regional law and 
Executive order/Governor regulation), the role of the local government is also to prepare the market demand by prioritizing development zones in industrial/commercial areas, offices, hotels and restaurants. In addition, the scheme to provide incentives and disincentives in the use of renewable energy is important to stimulate and to encourage more massive use, to prepare zoning for industrial areas for clean energy, and to provide vocational workers for the renewable energy sector.

The local government is also very open to cooperating with investors who will invest in the development of renewable energy in Bali. Currently, consultation and coordination phase are being held with the central government, business entities and non-governmental institutions to jointly review technical schemes and sustainable financing in the development of renewable energy.

\section{Conclusion}

Tourism sector is the economic backbone of the island, so that strong infrastructure is required to support it. Unfortunately, tourism sector is easily affected by natural and unnatural disaster, like Covid19 , in which we are still fighting to it. Therefore Bali government has been accelerating innovations to stimulate economic recovery, such as promoting small micro medium bussinesses, encouraging digital technology development, in wich all of these require reliable and sustainable energy. Green energy is one of the innovations for sustainabile development in Bali, to support sustainable tourism. It is expected that Bali is able to achieve energy independence by prioritizing the use of clean and renewable energy development, such as Solar Power Plant, Hydro Power Plant, and Bio Energy Plant such as WtE which currently these are available to be utilized. Surely, the development is conducted through mutually beneficial cooperation, technology transfer, and giving widely open job opportunities in energy sector. Some conclusions which can be drawn as follows:

a. There is widely open opportunity of Renewable Energy development and investment.

b. The Bali government vision of "Nangun Sat Kerthi Loka Bali" through Total Development Planning to achieve the new era of Bali, is emphasizing on the use of Clean Energy to keep Bali clean, green and beautiful, so that tourism sector will be supported with environmental friendly infrastructure.

c. The challenges are insufficient funds, incompetent human resources, and green energy technology.

d. Mutually beneficial between Central government, Bali Government, Academics, Business entities as investor is required to funding green energy infrastructure in supporting Bali economic recovery.

To achieve the dream of being a green island, the Governor of Bali has issued Governor Ordinance No. $45 / 2019$ that is strongly dedicated for the use of solar power, although not limited to other kind of renewable energies, and established the Taskforce led by the provincial leaders (Governor, Vice Governor and Secretary of the province) and consisted of inter-departments government head officers (Energy \& Mineral Resources, Public Works \& Spatial Planning, Environment \& Forestry, Industry \& Trades, and Law \& Regulations, Research \& Innovation Agency of Bali, Regional Development Planning Agency of Bali), PLN (UID-Bali), academicians, governor's experts unit, Center for Community Renewable Energy (CORE), Green Building Council Indonesia representative Bali ( $\mathrm{GBCl}-\mathrm{Bali})$, and communities represented by Amogasiddhi, a cooperative community business unit. In short, this team model resembles a collaborative-participative planning process.

With all of these efforts, solid vision, and strong will and motivation, may God will bless Bali's endeavor to be a green island with independent clean energy. Hopefully...

\section{References}

Bali Provincial Law No. 16/2009 concerning Spatial Planning of Bali Province 2009-2029 (Bali Provincial Sheet No. 16/2009, supplement to Bali Provincial Sheet No. 15) 
Bali Provincial Law No. 2/2019 concerning Long-Term Development Plan of the Province of Bali Province for 2005-2025 (Bali Provincial Sheet No. 2/2019, Additional Bali Provincial Sheet No. 2)

Bali Provincial Law No. 3/2019 concerning Medium Term Development Plan of the Province of Bali Province for 2018-2023 (Bali Provincial Sheet No. 3/2019, Supplement to Bali Provincial Sheet No. 3)

CORE (2019). Peta Jalan Pengembangan PLTS Atap: Menuju Bali Mandiri Energi. Denpasar: CORE (Centre Of Community Renewable Energy), Udayana University \& Greenpeace Indonesia.

Government Ordinance No. 70/2009 concerning Energy Conservation (State Sheet of the Republic of Indonesia No. 171/2009, Supplement to the State Sheet No. 5083)

Government Ordinance No. 79/2014 concerning National Energy Policy (State Sheet of the Republic of Indonesia Year No. 300/2014, Supplement to the State Sheet No. 5609)

Perusda Bali (2020) Paparan Rencana Bisnis dan Program Kerja Perusda Bali. Paper Presentation at Economics \& Development Administration Bureau, Regional Secretariat of Bali Province, 4 June 2020.

PLN (UID) Bali (2020) Sistem Kelistrikan Bali Menuju Green Tourism. Presentation in Forum Group Discussion at Regional Research and Inovation Agency (BARI), Denpasar, 30 Juli 2020.

Presidential Ordinance No. 22/2017 concerning National Energy General Planning (State Sheet of the Republic of Indonesia Year 2017 No. 43)

Purwanto, E. (2019). Jumlah Desa Wisata di Bali Naik 124 Persen. Retrieved on 05 August 2020 from https://bisniswisata.co.id/jumlah-desa-wisata-di-bali-naik-124-persen/

Republic of Indonesia Law No. 30/2007 concerning Energy (State Sheet of the Republic of Indonesia No. 96/2007, Supplement to the State Sheet No. 4746)

Republic of Indonesia Law No. 30/2009 concerning Electricity (State Sheet of the Republic of Indonesia No. 133/2009, Supplement to State Sheet No. 5052)

Wahono, J. (2020) Zero Waste Indonesia: Usulan Pengembangan Fasilitas Waste to Energy Terdistribusi untuk Membereskan Permasalahan Sampah. Presentation in Webinar of Disentangling Challenges, Optimization and Waste to Energy Opportunities, conducted by, Ministry of Energy \& Mineral Resources. 08 July 2020. 